\title{
Studies on Level of Infestation of Flat Headed Borer and Bark Eating Caterpillar on Terminalia arjuna and their Management using Insecticides
}

\author{
Preeti Tirkey $^{1}$, M. Chandrashekharaiah ${ }^{2 *}$, M.S. Rathore ${ }^{2}$, R.K. Singh ${ }^{1}$, \\ R.B. Sinha ${ }^{2}$ and Alok Sahay ${ }^{2}$ \\ ${ }^{I}$ Dr. C.V. Raman University, Kargi Road Kota, Bilaspur, Chhattisgarh, India \\ ${ }^{2}$ Basic Tasar Silkworm Seed Organisation, Central Silk Board, Bilaspur, Chhattisgarh, India \\ *Corresponding author
}

\section{Keywords}

Tasar silkworm, Flat headed borer, Bark eating caterpillar, Insecticides, Kargi Kota, Bilaspur

Article Info

Accepted:

07 December 2018 Available Online: 10 January 2019

\section{A B S T R A C T}

The Terminalia arjuna is an important deciduous tree species in India and is being utilized for both medicinal as well as sericulture purposes. The monoculture nature and continuous use of plantation for rearing of silkworm has profound negative effect on plants vigor, which attract variety of insect pests. Among them, the borer is very important pests on $T$. arjuna, due to their persistence attacking behavior, mainly on weak and young plants. Among the borer complex, Sphenoptera cupriventris Kerr. (Coleoptera: Buprestidae) and Indarbela quadrinotatais (Walker) (Lepidoptera: Cossidae) are important pests on $T$. arjuna which causes severe damage and reduce plants vigor gradually. Studies were conducted to evaluate the status of S. cupriventris and I. quadrinotatais on T. arjuna in around Bilaspur, Chhattisgarh and their management using different insecticides. The $S$. cupriventris infestation was significantly more in the block plantation compared to the natural plantation. Whereas, bark eating caterpillar incidence on $T$. arjuna was nonsignificant between block and natural plantation. The infestation of $S$. cupriventris and $I$. quadrinotatais on T. arjuna was $51.84 \%$ and $10.41 \%$ at Kargi Kota and $27.19 \%$ and $13.58 \%$ at Bilaspur, respectively. The distribution studies indicated that both the pests were negative binomial with contiguous distribution in Kargi Kota and Bilaspur. The insecticide evaluated date indicated that nearly $93.33 \%$ and $90.00 \%$ of plants treated with chlorpyrifos 20 EC @ $2 \mathrm{ml}$ and deltamethrin 2.8 EC @ $1 \mathrm{ml}$ found free from bark eating caterpillar damage. Whereas, imidacloprid 17.8 SL@ $0.6 \mathrm{ml} / 1$ and $0.4 \mathrm{ml} / 1$, dichlorvos 76 EC@ $2.5 \mathrm{ml} / 1$ and monocrotophos $36 \mathrm{SL} @ 2 \mathrm{ml} / 1$ treatments caused cent percent mortality of grubs in more than $90 \%$ plants.

\section{Introduction}

The Terminalia arjuna is an important deciduous tree belonging to the family Combretaceae. T. arjuna is distributed in Uttar Pradesh, southern Bihar, Jharkhand, Odisha, West Bengal, Chhattisgarh, Madhya Pradesh,
Uttar Pradesh, Deccan region (Telangana, Maharashtra, Andhra Pradesh, Karnataka, Kerala and Tamil Nadu) and Burma (Dwivedi, 2007). In India, the T. arjuna is being utilized for both medicinal purposes as well as commercial cultivation for tasar silkworm. The bark extract of $T$. arjuna is a potential 
cardio-protective agent and leaves are used for rearing of tasar silkworm by the rural and tribal people in Central India (Jolly et al., 1974; Dwivedi and Chopra, 2014). Presently, Government organizations and NGOs are being involved in the development of systematic plantation of $T$. arjuna, in addition to the rejuvenation of existing forest plantations for tasar sericulture activity. The systematic plantations are being used for seed cocoon production and forest plantations for commercial cocoon production. The $T$. arjuna has been considered as an economically important crop in India due to its multipurpose utility in the diversified fields.

In recent years, tasar sericulture is drawing attention of farming community due to increasing demand for tasar silk. Since, the overall demand for tasar silk far exceeds its production within India (Pastakia, 2015), the tasar sericulture is considered to be a potential area in the agriculture sector. For the success of the tasar culture, three components - feed, breed and seed are essential, of these, the feed is the vital component and decides the quality of the cocoon. The $T$. arjuna under block plantation is susceptible for variety of insect pests. Among them, the borer complex is very important pests, due to their persistence attacking behavior, mainly on weak and young plants. The loss caused in terms of the death of plants or otherwise, borer damage, which in turn affect growth and vigor of the plants. Among the borer complex, the Sphenoptera cupriventris Kerr. (Coleoptera: Buprestidae) and Indarbela quadrinotatais (Walker) (Lepidoptera: Cossidae) are important pests on $T$. arjuna and cause severe damage to the plants and reduce plants vigor gradually. The round-headed stem borer, Aeolesthes holosericea Fabr. (Coleoptera: Cerambycidae) is also an economically important borer on $T$. arjuna and their damage led to death of side branches or the entire plant. The literature survey indicated that the $S$. cupriventris and $I$. quadrinotatais occurrence in a great extent on $T$. arjuna in and around Bilaspur regions compared to A. holosericea, but with the scanty information of their infestation level and management (Prakash et al., 2010; Joshi, 2012).

Both, adults and grubs of $S$. cuprivenris are causing damage to $T$. arjuna plants. The adults lay eggs by excavating small pits on the bark and grubs feed on the barks as well as stem by boring into it. The exit hole made by the adults also causes damage to the plants. The gum exudation, bark splitting, rotting and fungus growth are common symptoms of this pest damage. Severe damage leads to the death of plants. Similarly, I. quadrinotatais construct larval galleries on the stem and feed within the galleries and bore into the stem and inflict severe damage to trees and reduce the vigor of the plant (Dhar et al., 1989; Kumawat and Swaminathan, 1990; George Mathew, 1997). The proper identification of susceptible stages and timely management practices enable the plants to recover from the pest damage and maintain the pest population below economic threshold level.

Majority of the studies follow the manual killing of borer pests by thrusting of wire or killing larvae and plugging the hole with mud after insecticide treatment against bark eating caterpillar and round headed borer. But, these methods will not serve the purpose against flat headed borer and also it is labor intensive to follow in the large area under block plantations. Use of chemicals is highly desirable for management of pests in the block plantations to ensure quality and vigor. Different chemicals like permethrin, carbaryl/sevin, bifenthrin, imidacloprid, chlorpyrifos, DDVP, etc. have been shown effective against the different borer pests in different crops (Zahid et al., 2015; Shivankar and Rao, 2004; Sandhu et al., 1987; Gupta et al., 2014). The present study is also one such 
study intended to examine the severity of bark eating caterpillar and flat headed borer in and around Bilaspur region and their management using different types of newer insecticides.

\section{Materials and Methods}

Studies were conducted at Bilaspur and Kargi Kota regions of Chhattisgarh state. The Bilaspur is situated in $22.0796^{\circ} \mathrm{N}, 82.1391^{\circ}$ E264 m AMSL. The climate is sub-tropical, semi-arid and monsoon type. Nearly 2.5 ha farm with 7000 T. arjuna plants @ 4×4 ft spacing was selected at Bilaspur. The plants are 5 years old. Whereas, the Kargi Kota is located in $22.1022^{\circ} \mathrm{N}, 82.14685^{\circ}$ E $330 \mathrm{~m}$ AMSL. The climate is similar to Bilaspur and about 17.5 ha areas having more than 15,000 T. arjuna plant at $4 \times 4 \mathrm{ft}$ spacing was selected for the study. A control field with 30 plants (no silkworm rearing has been conducted) in the Pendari campus, Bilaspur, which is near to Bilaspur Farm, was selected for the comparison.

Samplings were prepared during 2018 for $S$. cupriventris and I. quadrinotatais infestation in both Bilaspur and Kargi Kota farm. For sampling, the entire area was divided into the blocks and in each block, infested and healthy plants were recorded. The percentage and pattern of infestation was estimated and analyzed using statistical tools. Similarly, 20 randomly selected plants in the control field as well as Bilaspur farm were sampled separately for occurrence of $S$. cupriventris and $I$. quadrinotatais and the data were analyzed using t-test. To estimate the effect of infestation of $S$. cupriventris and $I$. quadrinotatais on total branches, a total of 40 each infested with the respective insect-pests as well as healthy plants were selected in the Kargi Kota for the observation. The number of branch per plant in the infested and healthy plants, was counted and per cent reduction was estimated.
To study the effectiveness of insecticides (chlorpyrifos 20 EC @ $0.05 \%, 0.1 \%$ and 0.2 $\%$, deltamethrin 2.8 EC @ $0.03 \%, 0.06 \%$ and $0.1 \%$, imidacloprid 17.8 SL @ $0.02 \%, 0.04$ $\%$ and $0.06 \%$, dichlorvos 76 EC @ $0.075 \%$, $0.15 \%$, and $0.25 \%$, monocrotophos 36SL @ $0.05 \%, 0.1 \%$ and $0.2 \%$ and azadirachtin 10000 PPM (EC) @ $0.0025 \%, 0.005 \%$ and $0.01 \%)$, the $S$. cupriventris and $I$. quadrinotatais infested plants were selected separately and marked before application of insecticides. Insecticides at selected concentration were treated on the selected 10 plants per treatment. Similar procedure was followed for all the insecticides and ten plants infested with the respective pests were selected as a control treatment.

Observations were recorded 30 days after insecticides treatment. For bark eating caterpillar, fresh feeding areas on the bark were considered for the recording activity of larvae. Whereas, a destructive sampling was followed for the flat headed borer, in each treatment the numbers of grubs dead and alive were recorded. The moribund grubs were also considered as dead during the observations. Further, the percentage reduction in infestation was computed for each treatment. The percentage data were transformed using ASINSQRT transformation and analyzed using ANOVA.

\section{Results and Discussion}

At Kargi Kota, the total area was divided into 20 blocks with an average $23.13 \pm 11.21$ rows per block and in each row on an average of $8.22 \pm 2.92$ (Mean \pm SD) plants were demarked. A total of $51.84 \%$ and $10.41 \%$ plants infested by the $S$. cupriventris and $I$. quadrinotatais, with an average of $4.08 \pm 2.02$ and $0.82 \pm 0.41$ plants per row, respectively. The $S$. cupriventris infestation was significantly higher than the $I$. quadrinotatais $(\mathrm{t}=8.75$; $\mathrm{df}=20 ; \mathrm{p}=0.01)$. The infestation of the 
respective pests were ranged $8.68 \%$ to 76.21 $\%$ and $2.71 \%$ to $22.60 \%$. At Bilaspur, the total area was divided into 5 blocks and in each row on an average of $16.85 \pm 5.92$ plants were demarcated. Nearly, $27.19 \%$ and 13.58 $\%$ of plants were infested by the $S$. cupriventris and I. quadrinotatais, respectively. The average plants infested in a row by the respective insect-pests was $8.34 \pm 3.86$ and $3.99 \pm 1.99$. The $S$. cupriventris infestation was significantly more in Bilaspur compared to I. quadrinotatais $(\mathrm{t}=3.206$; $\mathrm{df}=3$; $\mathrm{p}=0.02$ ).

The $S$. cupriventris and I. quadrinotatais found a negative binomial distribution with contiguous distribution both in Kargi Kota and Pendari farm (Variance > Mean). The $S$. cupriventris infestation was significantly more in the block plantation compared to the natural plantation $(\mathrm{t}=9.32 ; \mathrm{df}=18 ; \mathrm{p}=0.01)$. Whereas, bark eating caterpillar incidence on $T$. arjuna was non-significant between block and natural plantation $(\mathrm{p}=0.416)$. Significant reduction in the branches was also recorded in the plants infested by the flat-headed borer $(\mathrm{t}=17.74 ; \mathrm{df}=39 ; \mathrm{p}<0.01)$ and bark eating caterpillar $(\mathrm{t}=12.30 ; \mathrm{df}=39 ; \mathrm{p}<0.01)$ infestation compared to healthy plants. A total of $47.45 \%$ and $44.03 \%$ reduction in branches due to an infestation of bark eating caterpillar and flat headed borer, respectively. In each plant, nearly $37.79 \%$ and $57.35 \%$ of branches in the infested plants were affected by the flat-headed borer at Bilaspur and Kargi Kota, respectively. Nearly $85 \%$ of the bark eating caterpillar infestation restricted to the base of the branches or near cut portion of plants during pollarding and $15 \%$ of infestation was recorded on the main stem (Fig. 1-3).

Table.1 Effect of different insecticides with different concentration on bark eating caterpillar and flat headed borer

\begin{tabular}{|c|c|c|c|c|}
\hline Treatments & $\begin{array}{l}\text { Qt. applied } \\
(\mathrm{ml} / \mathrm{l})\end{array}$ & $\begin{array}{c}\text { Kg a.i/ } \\
\text { ha }\end{array}$ & $\begin{array}{c}\text { Reduction in bark } \\
\text { eating caterpillar } \\
(\%) \text { in } 30 \text { DAS }\end{array}$ & $\begin{array}{c}\text { Reduction in flat headed } \\
\text { borer grubs }(\%) \text { in } 30 \\
\text { DAS }\end{array}$ \\
\hline \multirow[t]{3}{*}{ Chloropyrifos20 \% EC } & 0.5 & 0.15 & 63.33 & 46.67 \\
\hline & 1 & 0.3 & 76.67 & 53.33 \\
\hline & 2 & 0.6 & 93.33 & 63.33 \\
\hline \multirow[t]{3}{*}{ Deltamethrin $2.8 \%$ EC } & 0.3 & 0.09 & 60.00 & 53.33 \\
\hline & 0.6 & 0.18 & 70.00 & 53.33 \\
\hline & 1 & 0.3 & 90.00 & 50.00 \\
\hline \multirow[t]{3}{*}{ Imidacloprid $17.8 \%$ SL } & 0.2 & 0.06 & 46.67 & 86.67 \\
\hline & 0.4 & 0.12 & 56.67 & 96.67 \\
\hline & 0.6 & 0.18 & 70.00 & 100.00 \\
\hline \multirow[t]{3}{*}{ Dichlorvas $76 \%$ EC } & 0.75 & 0.225 & 46.67 & 76.67 \\
\hline & 1.5 & 0.45 & 53.33 & 86.67 \\
\hline & 2.5 & 0.75 & 73.33 & 90.00 \\
\hline \multirow[t]{3}{*}{ Monocrotophos 36\% SL } & 0.5 & 0.15 & 60.00 & 86.67 \\
\hline & 1 & 0.3 & 66.67 & 86.67 \\
\hline & 2 & 0.6 & 73.33 & 90.00 \\
\hline \multirow{3}{*}{$\begin{array}{l}\text { Azadirachtin10000 PPM } \\
\text { (EC) }\end{array}$} & 0.5 & 0.15 & 40.00 & 43.33 \\
\hline & 1 & 0.3 & 46.67 & 43.33 \\
\hline & 1.5 & 0.45 & 60.00 & 56.67 \\
\hline \multicolumn{3}{|c|}{ Control } & 16.67 & 20.00 \\
\hline
\end{tabular}

Note: DAS = Days after spray 
Fig.1 The T. arjuna infested with the Indarbela quadrinotatais and Sphenoptera cupriventris
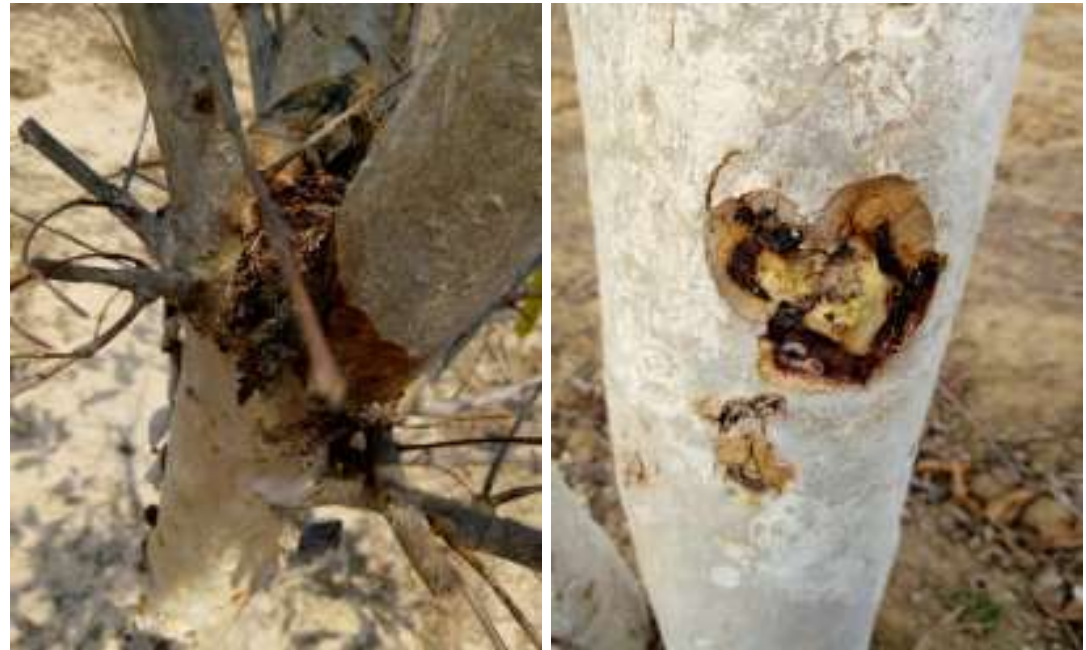

Fig.2 Infestation of flat headed borer and bark eating caterpillar in natural and block plantation. The asterisk indicated a significantly higher occurrence

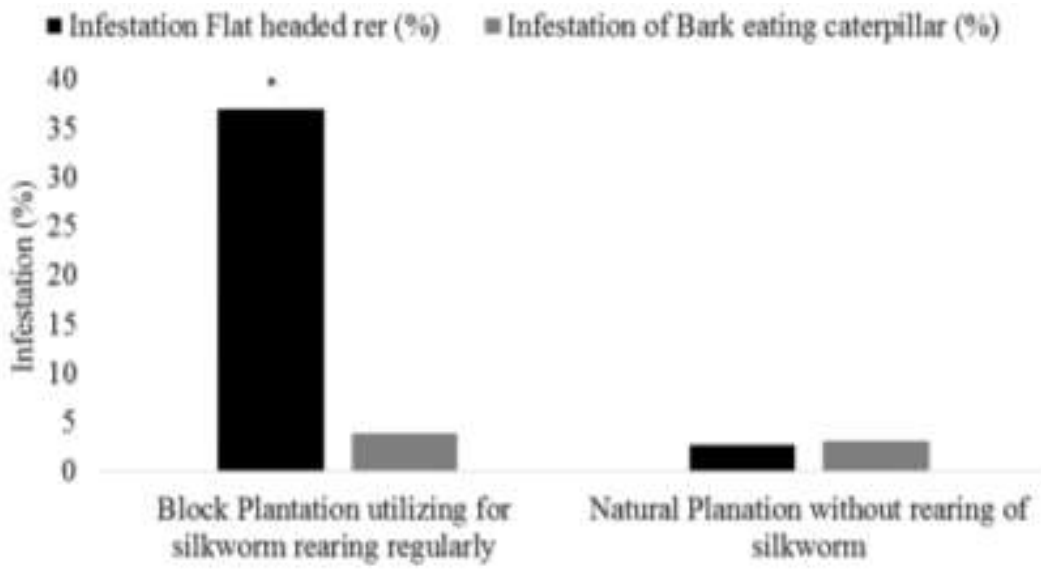

Fig.3 Number of healthy and infested branches in the T. arjuna due to the flat-headed borer at Pendari and Kota

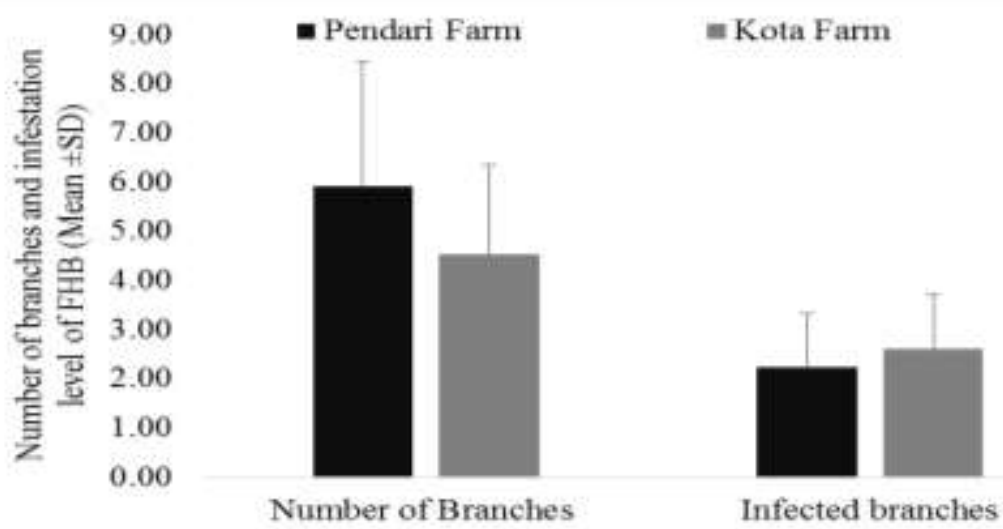


The feeding inhibition by the bark eating caterpillar varied significantly between the insecticides $(\mathrm{F}=12.07 ; \mathrm{df}=18,56 ; \mathrm{p}<0.01)$. The perusal of insecticide evaluated date indicated that chlorpyrifos 20 EC @ $2 \mathrm{ml}$ and deltamethrin 2.8 EC @ $1 \mathrm{ml}$ found inhibited bark eating caterpillar feeding by $93.33 \%$ and $90.00 \%$ of plants, respectively. The next highest was recorded in the treatments chlorpyrifos $20 \%$ EC @ $1 \mathrm{ml}(76.66 \%)$, dichlorvos $76 \%$ EC@ $2.5 \mathrm{ml}(73.33 \%)$, monocrotophos 36\% SL @ 2 ml (73.33\%), imidacloprid 17.8\% SL @ $0.6 \mathrm{ml}(70.00 \%)$ and deltamethrin $2.8 \%$ EC @ 0.6 ml/1 (70.00 $\%)$. The highest mortality of flat-headed borer grubs was recorded in the imidacloprid 17.8 SL@ 0.6 ml/1 (100\%), @0.4ml/1 (96.67\%), dichlorvos 76 EC@ $2.5 \mathrm{ml} / \mathrm{l}(90.00 \%)$ and monocrotophos $36 \mathrm{SL} @ 2 \mathrm{ml} / \mathrm{l}(90.00 \%)$ treatments compared to other treatments $(\mathrm{F}=52.59 ; \mathrm{df}=18,56 ; \mathrm{p}<0.01)$. The lowest concentration of imidacloprid (@0 $0.2 \mathrm{ml} / \mathrm{l}$ ), dichlorvos (@ $1.5 \mathrm{ml} / \mathrm{l}$ and $0.75 \mathrm{ml} / \mathrm{l}$ ) and monocrotophos (@ $0.5 \mathrm{ml} / \mathrm{l}$ and $1 \mathrm{ml} / \mathrm{l}$ ) were also more effective compared to chlorpyrifos $20 \%$ EC, deltamethrin $2.8 \%$ EC and azadirachtin 10000 PPM (EC) (Table 1).

The food plants used for rearing of silkworm in tasar sericulture must be well maintained and free from pest and diseases. But, due to intensive sericulture practices, the host plants become susceptible for pest and diseases (Dhar et al., 1989). The biotic factors further devitalize the host plants and ultimately reduce the leaf production as well as their quality. The $S$. cupriventris and $I$. quadrinotatais were recorded as a dominant stem feeding insect-pests on $T$. arjuna at Kargi Kota and Bilaspur regions. The higher incidence of pests might be due to continues utilization of host plant for the rearing of the silkworm and their low resistant capacity against the insect-pests. The tasar silkworm host plants have to invest more energy for production of foliage before (June-July) as well as after (August-December) rearing of the silkworm, so that, in this process, the host plants might allocate less energy for maintaining immunity to defend against the biotic factors. Imbalance of such energy trade-off between leaf production and immunity, has greatly affected the immunity of the plants (Coley et al., 1985). About 51.84 $\%$ and $27.19 \%$ of $S$. cupriventris infestation were recorded at Kargi Kota and Bilaspur, respectively. Dhar et al., (1989) reported various flat headed stem borer species like Psiloptera fastuosa and $S$. konbierensis infesting the $T$. arjuna and T. tomentosa and there damage up to 40 per cent. The highest infestation in the Kargi Kota might be due to the continuous utilization of host plants since more than 10 years. Whereas in Bilaspur, the plantation was utilizing since last 5 years only (Buwai and Trlica, 1977). Further, the $S$. cupriventris was comparatively more in the block plantation, on which tasar silkworm rearing has been practiced since several years, compared to the natural plantation. Predisposing factors like drought-stressed, newly planted or those with trunk wounds enhance the flat headed borer infestation (Taun Beddes, 2014). The bark eating caterpillar infestation was $10.41 \%$ and 13.58 $\%$ in Kargi Kota and Bilaspur, respectively. Main factors like persistent attacking behavior of pests, poor vigor of plants and alternative host plants nearby rearing fields might be favor the bark eating caterpillar (George Mathew, 1997).

The flat-headed borer and bark eating caterpillar found a negative binomial pattern with contiguous distribution at Kargi Kota and Bilaspur. The distribution depends on the availability of resource and space for the feed and breed. Contiguous distribution means localized and aggregation of the pest population. This might be due to localized susceptibility and resistance plants for the flat headed borer and bark eating caterpillar. The 
flat-headed borer and bark eating caterpillar seems to be persistence pest and multiply consistently in a localized patch. The infestation of flat-headed borer was significantly higher in the block plantation which has been utilized for silkworm rearing continuously over several years compared to the natural plantation. Whereas, the infestation of bark eating caterpillar (\%) did not differ significantly between the block and natural plantation. Significant reduction in the branches was also been recorded due to flat headed borer and bark eating caterpillar infestation compared to healthy plants. Joshi (2012) reported $26 \%$ flat headed borer infestation on young $T$. arjuna plantation at Bilaspur region. The I. quadrinotatais highly polyphagous pests and its infestation was recorded on more than 40 host plants (George Mathew, 1997). Alternative hosts, as well as age, are the major factors influence this pest to infest and build-up in the plantation. Once the pest had infested, its persistence behavior helps to multiply continuously due to the availability of host plants.

The grubs of flat-headed borer reduced considerably in more than $90 \%$ of plants due to the application of imidacloprid $17.8 \% \mathrm{SL}$ @ $0.6 \& 0.4 \mathrm{ml}$, dichlorvos $76 \% \mathrm{EC}$ at 2.5 $\mathrm{ml} / \mathrm{l}$ and monocrotophos $36 \% \mathrm{SL} 2 \mathrm{ml} / \mathrm{l}$. The insecticides like azinphos-methyl as a foliar spray, methiocarb, azinphos-methyl and carbosulfan application on the stem as a dust and soil application of imidacloprid found effective against buprestid pests on stone-fruit (Ben-Yehuda, 2000). Further, nurelle-D 505EC and triazofos 40EC @ 75ml and synergistic effect in bordeaux mixture (copper oxychloride $75 \mathrm{~g}+$ lime $3 \mathrm{~kg}+$ water $10 \mathrm{l}$ ) treatments reduced flat headed borer in stone fruit orchard (Zahid et al., 2015). The insecticide trial indicated that chlorpyrifos 20 \% EC @ 2 ml and deltamethrin 2.8\% EC @ $1 \mathrm{ml}$ inhibited bark eating caterpillar feeding in the $93.33 \%$ and $90.00 \%$ of the plants, respectively. The chemicals recommended for its control were monocrotophos (dimecron) $(0.1 \%)$, quinalphos (ekalux) $(0.1 \%)$ or fenvalerate (sumicidin) $(0.08 \%)$. Spot application of any of the above chemicals, using a rocker sprayer drenching the borer hole, sleeve and the surrounding bark to control this pest (George Mathew, 1997).

\section{References}

Ben-Yehuda, S., Assael, F., and Mendel, Z., 2000. Improved chemical control of Capnodistene brionis and $C$. carbonaria in stone-fruit plantations in Israel, Phytoparasitica. 28:27. https://doi.org/10.1007/BF02994021.

Buwai, M., and Trlica, M.J., 1977. Multiple defoliation effects on herbage yield, vigor, and total nonstructural carbohydrates of five range species. Journal of Range Management. (3):164-171.

Coley, P.D., Bryant, J.P., and Chapin, F.S., 1985. Resource availability and plant anti-herbivore defense. Science. 230:895-899.

Dhar, S.L., Mandal, K.C., Singh, R.N., Bhengara, S.R., and Sen Gupta, K., 1989. Biocoenology and community structure of pests and predators in tropical tasar region Ranchi, India. Sericologia. 29:67-86.

Dwivedi, S., 2007. Terminalia arjuna Wight and Arn. A useful drug for cardiovascular disorders. $J$. Ethnopharmacol. 1:114-129.

Dwivedi, S., and Chopra, D., 2014. Revisiting Terminalia arjuna - An Ancient Cardiovascular Drug. Journal of Traditional and Complementary Medicine. 4(4): 224-231.

George Mathew, 1997. Management of the bark caterpillar Indarbela quadrinotata in forest plantations of Paraserianthes falcataria. KFRI 
Research Report-122, Kerala Forest Research Institute Peechi, Thrissur.

Gupta, D., Naram, S., and Bhatia, R.S., 2014. Incidence, intensity and management of bark eating caterpillar, Indarbela sp. infesting fruit trees in Himachal Pradesh, India. Pest Management in Horticultural Ecosystems. 20(1):1-7.

Jolly, M.S., Sen, S.K., and Ahsan, M.M., 1974. Tasar culture, Ambika Publishers, Bombay.

Joshi, K.L., 2012. A new stem borer infesting tasar silkworm food plants, The Scientific Temper. 3(1\&2): 17-20.

Kumawat, S.R., and Swaminathan, R., 1990. Relative preference of jujube (Zizyphus mauritiana Lamk.) cultivars by bark eating caterpillar, Indarbela quadrinotata (Walker). Indian journal of Entomology. 52(2): 336-338.

Pastakia, A., Alam, S., Satyanarayan, K., Pandya, H., Dahal, B.R., and Khandai, R., 2015. Reel of fortune Building inclusive value chains: the case of tasar silk in Bihar and Jharkhand. PRADAN, New Delhi.

Prakash, P.J., Singh, J.R.S., Sanjeeva Roa, B.V., Mahobia, G.P., Vihaya Kumar, M., and Prasad, B.C., 2010. Population dynamics of round headed stem borer, Aeolesthes holosericea
Fabr. (Coleoptera: Cerambycidae) in arjun ecosystem of Andhra Pradesh and its correlation with abiotic factors. Entomon, 35(2): 143-146.

Sandhu, G.S., Sohi A.S., and Batra, R.C., 1987. Comparison of different control methods for the management of bark eating caterpillar, Indarbela quadrinotata Walker (Metarbelidae: Lepidoptera) infesting fruit and avenue trees in Punjab. Punjab Horticultural Journal. 27(3-4): 255259.

Shivankar, V.J., and Rao, C.N., 2004. Menace of bark eating caterpillar (Indarbela sp.) in citrus orchards of Maharashtra. Pest Management in Horticulture Ecosystems. 10(2):203-206.

Taun Beddes, 2014. Pacific flat headed borer and flat headed apple tree borer, Utah State University Extension and Utah Plant Pest Diagnostic Laboratory, ENT-170-14PR, February 2014.

Zahid, M., Salman, M., Khan, S.A., Alamzeb and Khan, I., 2015. Surveillance and control of peach flat-headed borer, Sphenoptera dadkhani (Oben.) in Plum orchards of Khyber Pakhtunkhwa, Pakistan. Sarhad Journal of Agriculture. 31(1): 30-36.

\section{How to cite this article:}

Preeti Tirkey, M. Chandrashekharaiah, M.S. Rathore, R.K. Singh, R.B. Sinha and Alok Sahay. 2019. Studies on Level of Infestation of Flat Headed Borer and Bark Eating Caterpillar on Terminalia arjuna and their Management using Insecticides. Int.J.Curr.Microbiol.App.Sci. 8(01): 598-605. doi: https://doi.org/10.20546/ijcmas.2019.801.067 